\title{
Travel back to school: use of humour in intertwining of objective authenticity and staged experiences
}

\author{
Maja Turnšek \\ University of Maribor, Slovenia \\ maja.turnsek@um.si
}

\section{Tatjana Zupančič}

Tourist Association Črnomelj, Slovenia

tatjana.zupancich@gmail.com

\section{Barbara Pavlakovič}

University of Maribor, Slovenia

barbara.pavlakovic@um.si

\begin{abstract}
From living museums to heritage escape rooms, edutainment is becoming a norm in heritage interpretation, yet not much is known of the specific role humour plays in the creation and performance of such educational products. This paper explores concepts of authenticity, functions of humour, and experience design dimensions in an in-depth case study of a tourism product. The product "Smart Head Primary School" is a re-enactment of teaching as it occurred in the 1950s in Slovenia. It became very popular primarily due to its extensive inclusion of humour. The product uses the role of a strict teacher to interpret to the "pupils" (visitors) the prime elements of the region's heritage. To analyse the intertwining of humour with heritage interpretation, the authors combine two research methods: (a) a survey distributed to the visitors of the product, and (b) the in-depth analysis of a transcribed video-recording of a sample performance including the self-analysis and the reflections of one of the "teachers". The results show that with the use of humour, visitors are able to perceive and recognize the difference between objective and constructive authenticity more effectively.
\end{abstract}

Keywords: tourism, humour, authenticity, experience economy, quasification, heritage interpretation. 


\section{Introduction}

Edutainment in tourism has long been an important element in at least two areas enriching tourists' experiences. Firstly, edutainment is often used in heritage interpretation, where tourism workers have long been faced with the dilemma of how to provide factual information about local heritage attractions in an inspiring and entertaining manner and at the same time stay authentic while providing local knowledge and facts. Secondly, there is the area of staged entertainment whereby experiences are built on storytelling, performance and interactive engagement with the audiences in the staged experiences. With the rise of the so-called experience economy (Pine and Gilmore 1999), we are witnessing a trend where the two worlds become part of the same experience: the world of heritage interpretation and the world of staged experiences, intertwined to enhance the tourists' entertainment and their knowledge of a destination's heritage.

This paper focuses on a case study of a staged tourism experience enriched with the use of humour. The tourism product "Smart Head Primary School" is designed as a one-hour reenactment of teaching as it occurred in the 1950s. It was selected for analysis due to its popularity in Slovenia primarily because of its humorous characteristics. The paper is structured into the following sections: as a contextual introduction, we provide an overview of the experience economy, its critical counter-concept of the Disneyfication of society and the mediating role of the concept of quasification. We then discuss the term authenticity in tourism studies, its relation to staged experiences and the role of humour in more modern understandings of authenticity in tourism. Further on, we discuss the role of humour in designing staged tourism experiences and reflect upon the link between the three functions of using humour in a tourism product and the four dimensions of experience design. The empirical analysis of the "Smart Head Primary School" is then presented, using two research methods: in-depth analysis of a transcribed video-recording of a sample performance including reflections by one of the "teachers" (one of the paper's authors) and a survey distributed to the visitors of the product.

\section{Literature review}

\subsection{Experience economy: "Let's throw in the cake for free"}

Pine and Gilmore $(1998 ; 1999)$ claim that the last few decades have brought about a new stage in the economic progress from the service economy into the experience economy. Their "birthday cake metaphor" is now a common element of experience design teaching in tourism studies. The metaphor simplifies the history of economic progress using the example of the fourstage evolution of the birthday cake. In the agrarian economy, the birthday cake had to be made from scratch, mixing farm commodities for a reasonably low price. With advancement into the second stage, the industrial economy, parents were able to buy premixed ingredients for a higher added value, hence higher price. In the third stage of economic progress, the service economy, parents ordered ready-made cakes that cost ten times as much as the packaged ingredients. And finally, in the fourth stage, the experience economy, parents neither make the birthday cake nor host the birthday party. Instead, they pay a much higher price to outsource the entire party to a company that "stages a memorable event for the kids - and often throws in the cake for free" (Pine \& Gilmore 1998: 97). 
From a sociological and more critical point of view, Bryman (1999) claims that what we increasingly see is the Disneyfication of the consumption experiences of our everyday lives. The trend of Disneyfication, Bryman (1999) claims, is composed of four main dimensions that have long been part of the Disney theme parks business model: theming, hybrid consumption, merchandising and performative emotional labour. Theming is combining the elements of an experience under an overall fun theme, such as the theming of restaurants, hotel chains or shopping malls into themes like "Ancient Rome". Hybrid consumption is the collection of multiple consumption opportunities, which become interlocked and increasingly difficult to distinguish, such as the resemblance of some shopping malls to theme parks and vice versa, with the goal of selling more by adding food, picture taking, gifts, etc. Merchandising refers to developing copyright images and logos, and increasing the income via selling products made under licenses or rights to do so. Finally, work in the experience economy includes a high level of "performative labour" (a form of emotional labour, see Hochschild 1983) whereby employees become actors on the workplace stage, need to present cheerfulness and convey the impression that they are having fun too and therefore not engaging in real work.

In discussing the terms of experience economy and Disneyfication, humour seems to act as a mediator between the "objectively authentic" versus the "fake". Beardsworth and Bryman (1999; 2001) introduced the concept of "quasification" in relation to experience economy products such as themed restaurants. Quasification entails the creation of "fakes", but not the kind of fakes which are intended to deceive the beholder into believing they are "real". Rather, Beardsworth and Bryman (2001) argue, the intention is that the guest should be "in on the joke", and hence be diverted, entertained and impressed by the skill, scope or scale of the artifice, as is for example the case of putting taxidermied animals in museums behind the glass to "protect" the visitors.

\subsection{Experience design and humour}

An experience is defined by Pine and Gilmore (1998) as a result of the process in which a company intentionally uses services as the stage, and goods as props, to engage individual customers in a way that creates a memorable event (for example transforming a taxi ride from a mere service of getting from point A to point B into an entertaining event enjoyed for its own value). Given the centrality of the concept for the tourism industry, it is not surprising that hospitality and tourism studies have a long tradition of conceptualising experiences, drawing mostly from psychology, economics and sociology. Walls et al. (2011) provide a historical overview of this discussion and state that the study of experiences in tourism generally followed three directions: creating a taxonomy or classification of experiences; examining the causes of or explaining an experience; and comparing the relationship between experiences and other constructs.

Regarding the taxonomy and classification of experiences, we turn here again to Pine and Gilmore (1998) who were mostly concerned with the question of how to design an experience in a way that "sells" and thus to stage it in a memorable way. They advise to theme the experience, harmonize impressions with positive cues, eliminate negative cues, mix in memorabilia and engage all five senses. While commodities, goods, and services are external to the buyer, experiences are inherently personal, existing only in the mind of the guests, derived from the interaction between the staged event (like a theatrical play) and the individual's state of mind. Pine and Gilmore propose two dimensions according to which experiences can be analysed. The first is guest participation; the level to which guests engage with the performance. 
The second is immersion; the level of environmental relationship, which unites customers with the event or performance. The two dimensions serve to sort experiences into four broad categories or realms, which themselves become dimensions of experiences, with some attractions such as Disney World managing to include all four dimensions: entertainment, education, escape and aesthetic. These dimensions later served for several applications in terms of measurements of the quality of the experience and typologies of experiences (e.g., Jurowski 2009; Mehmetoglu \& Engen 2011; Kim, Ritchie \& McCormick 2012; Radder \& Han 2015; Oh, Fiore \& Jeoung 2007). The latest measuring scale of the four dimensions of experiences was developed by Oh, Fiore and Jeoung (2007) who define the four dimensions as the levels to which guests judge that they are entertained (entertainment), learn something new (education), diverge to a new self (escape) and indulge in the experience's environment (aesthetics).

One of the four core dimensions of Pine \& Gilmore's typology of experiences is entertainment, where the most common operationalisation of the dimension is the extent to which the guests have fun within the experience. By analysing 14 cases of tourism entertainment products with a strong mix of pedagogic intent with commercial entertainment, Pearce (2008) identified humour-oriented guided tours as a common form of entertaining tourism, next to products such as cultural shows, dance performances, theme park presentations, and film and video presentations tailored exclusively for visitors. These cases, Pearce (2008) argues, are a demonstration of the growing prominence of fun and enjoyment as the principal motive for various types of travel. Furthermore, Pearce (2008) argues that these products are examples of a postmodern push towards creating hyper-real situations, but this does not necessarily need to be taken in the critical sense that the audience is being duped, but rather as a contemporary opportunity to explore more fully the psychological and emotional rewards which tourism audiences can achieve in these settings.

The role of humour is providing flexibility of thought, and enhancing openness to friendly interactions with other people, which may in turn lead to increases in creativity, memory, problem solving, altruism, and prosocial behaviour (Attardo 2014). Humour is one of the 24 character strengths (more exactly among strengths of transcendence) identified by psychologists and these strengths and virtues are viewed as important contributors to a life of fulfilment and satisfaction (Peterson \& Seligman 2004). This is supported by Barnett and Deutsch's (2016) idea that humour induces subjective well-being, including self-esteem, relational satisfaction and improved relationships. Hence, humour is not just a way to make tourists feel better and enjoy the moment, it is also a way to get in touch with fellow travellers and most importantly with themselves. This thought is a transformation of Heidegger's (1962) concept of authenticity into the tourism sphere. To paraphrase Knudsen, Rickly and Vidon (2016), authenticity is a humorous fantasy that reassures us that, despite the fact that we encounter the everyday alienation from our true being, there remains certain humorous tourism places where this alienation can be avoided and where we as tourists can learn, laugh, emulate, and re-create ourselves.

Humour itself is a rather new topic of research in the field of tourism, since it was mostly discussed by philosophers, psychologists and linguists (Slivar, Periša \& Horvat 2018). Only recently Frew (2006a; 2006b) and to a greater extent spurred by Pearce and Pabel's work, we see humour empirically entering the field of experience design in tourism studies (Pearce 2009; Uzelac, Nasar \& Lacbawan Jr. 2015; Pabel \& Pearce 2015; 2016; 2018; Francesconi 2017; Slivar, Periša \& Horvat 2018). The definition of humour applied in tourism studies is humour as a form of an enjoyable, non-serious communication in which the stimulus may produce 
amusement, diversion and laughter, maintaining a good cheerful mood (Frew 2006b; Pabel \& Pearce 2018; Slivar, Periša \& Horvat 2018). Frew (2006a; 2006b) was amongst the first to identify the pivotal role of humour in the motivation and ultimate satisfaction levels of tourists, since it creates high levels of post-trip satisfaction, repeat visits, positive word of mouth recommendation and consequently helps to enhance the economic and social state of the destination. This is also confirmed by Gaoa \& Kerstetterb (2018), who state that using humour evokes positive emotions and a feel-good feeling about the situation tourists are in, which is a state that is desirable during a vacation or travel.

As Pabel \& Pearce (2018) recognise, the perception of humour is a subjective phenomenon and depends on the individual's cultural background, their mood, and past experiences. There are several ways of using humour in tourism. Pearce (2009) divided the existing studies into research work concerning humour to attract tourists (humour in tourism promotion), on-site humour (while experiencing a tourism product), humour about tourists and humour created by tourists. The benefits of using humour in promotional material like videos, advertisements, leaflets etc. are presented as the appeal of humour as an attention grabber and its emotional and cognitive impact on the audience (Slivar, Periša \& Horvat 2018; Francesconi 2017).

On-site humour is regarded as formal humour, i.e. the offer of humorous presentations and events as a source of attraction for tourists (Frew 2006a). Other studies focused on the usage of informal humour in guided tours. Uzelac, Nasar \& Lacbawan Jr. (2015) write that when tour guides crack jokes, not only do they break the one-way flow of narration, but they also creatively expand their presence and constantly draw the tourists' attention into the performance. The humorous instances can for example be observed in the guides' choice of words, their facial expressions, nonverbal communication, funny acts, jokes, friendliness toward the customers, their welcoming attitude, professionalism and skill, an ease of approachability and not making fun of tourists in a negative way (Lehtovuori 2016).

The issue of making fun of tourists or one's own culture in tourism interpretation and entertainment was amongst the first analysed by tourism scholars on the topic of humour in tourism (Sweet 1989; Evans-Pritchard 1989). In addition, humour in tourism is often used on souvenirs that have a funny meaning or look, including postcards, t-shirts, fridge magnets, travel writing, humorous photographs and video blogs (Pabel \& Pearce 2016). Some authors also highlight the importance of humour between hospitality employees, between employees and managers, and between all staff and customers (Frew 2006b; Pabel \& Pearce 2016).

Humour by tour guides can be used as a playful way to provide instructions to tourists and to control certain tourist behaviours (Lehtovuori 2016; Pabel \& Pearce 2018). Pabel and Pearce (2018) introduce a framework for selecting humour in diverse tourism settings especially useful for tour guides and other tourism industry professionals. Pearce (2009) presented a model of three functions of using humour in a tourism product: humour establishes visitor comfort levels, assists visitor concentration and establishes connections to presenters. The model was tested in Pabel and Pearce's (2016) study, which showed the strongest positive correlation of guides' humour with making respondents feel comfortable at the setting. There was also a positive correlation of humour with the concentration and connection outcomes, however to a lesser extent. Other empirical applications of the model show that appropriate humour can lead to more engaging and enjoyable experiences for tourists even in unpleasant situations (Pabel \& Pearce 2015).

The experience economy product design approach proposes "that work is theatre and every business a stage" (Pine \& Gilmore 1999). "Staging" has long been a part of research interest in 
tourism, for example in the forms of theme parks such as Disney, historically themed restaurants, and re-enactments of history (e.g., Moscardo and Pearce 1986, Chhabra, Healy \& Sills 2003). In the classical sociological understanding of staging (Goffman 1959), this refers to the acceptance of social roles and role-playing. In leisure and tourism studies, however, staging is a concept with a long tradition of often quite opposed discussions, starting mostly with MacCannell's (1973) critique of staged authenticity in tourism settings. In the next section, we will thus turn to the discussion of authenticity as one of the most salient and disputed concepts in tourism studies.

\subsection{Tourism, authenticity and humour}

Humour in "staged" settings is of interest to tourism researchers of heritage interpretation, performed by tour guides at a destination (Zhang \& Chow 2004) or within more structured, themed products that follow Pine and Gilmore's propositions of building experiences. Moscardo (1996) developed a model of mindfulness in heritage interpretation settings. She claims that humour, analogies, metaphors, opportunities to ask questions, provision of variety, and structuring information aid the visitors towards a more mindful and thus more satisfied experience whereby they can learn more. The strategic use of humour becomes most beneficial and tourists are likely to be more mindful of and engrossed with the positive emotions associated with their experience. This is a positive outcome of tour guide interpretation, when correctly balancing the authentic facts and humour (Pabel \& Pearce 2018). This balance of authentic facts versus entertaining (and assumingly more easily marketable) experiences has been part of a long-term and vivid discussion amongst the tourism scholars for almost fifty years.

In tourism studies, authenticity is often acknowledged as a universal value and an essential driving force that motivates tourists to travel to distant places and times (Kolar \& Žabkar 2010). The concept originates from the philosophical thought of Heidegger (1962) who emphasised the fusion of self and the external world and introduced the concept as an awareness of all beings and a fulfilment of being fully alive and mindful. In the field of tourism studies, the debate on authenticity was sparked by MacCannell's (1973) conceptualisation of staged authenticity. He stated that the purpose of tourist travel is to seek authenticity and that a driver of all tourist behaviour is the quest for spontaneous, transparent, insightful views of places. Based on the works of Goffman (1959), MacCannell developed the idea of front and back stage in tourism settings, as the condition for the permanent failure of the tourist to experience authenticity. According to this idea, authentic experiences happen in the back stage of the tourism setting, a real life that is not staged for tourism purposes only. It can be described as authentic, not artificial, with local atmosphere, off the beaten track, and life as the natives live it (MacCannell 1973). As a foundation of authenticity in tourism, MacCannell's idea was later used and upgraded by other researchers in this field. Cohen (1988), for example, discussed authenticity and commoditization of tourism and argued that not only should the presented experiences be perceived as objectively real or staged, but also that tourists can perceive them as either one or the other, even when for example they are real but are perceived as staged.

Wang (1999) provided an overview of the discussion on the concept and divided approaches to understanding authenticity into three different camps: objective authenticity, constructive authenticity and existential authenticity. The traditional, most conservative understanding of the concept is objective authenticity whereby expert knowledge is used as the means of identifying genuinely authentic elements of tourism products (e.g., what is authentic in a staged experience is what is true according to historical knowledge, thus paying attention to "fake" interpretations). 
Constructive or symbolic authenticity recognises the existence of power relations and interests in defining what is or is not objective, and stipulates that what is authentic is always socially constructed (e.g., recognising that even in cases where a staged experience is following historical knowledge, the knowledge itself was constructed through societal interests). The final approach to the debate is the concept of existential authenticity which is regarded as a "potential existential state of being that is to be activated by tourist activities and can have nothing to do with the authenticity of toured objects" (Wang 1999: 352).

Postmodern approaches to authenticity extend even further and decide that because of its constructive nature, the concept of authenticity is either useless or is a fantasy (Vidon, Rickly $\&$ Knudsen 2018). The continuation of the debate changed the perception of the authenticity concept from the representation of real, true and original, to sincere and effortful, expressing involvement and the quality of the encounter (Pearce 2005). Knudsen, Rickly \& Vidon (2016) argue that authenticity can be vague and unattainable, but it drives our individual and collective travel behaviour in significant ways, hence it is regarded as presenting a motivation to go in search of tourism experiences in the first place. The authors continue by explaining that a fantasy is a story that reconciles why a "thing" is missing from our life and that we can fulfil our desires for the authentic through travel. Tourism becomes a symbolic opposite of our everyday lives and as tourists, we can take a different role or personal characteristics that we wish to have (Sedmak 2010).

The transformation of the conceptualisation from rational to emotional suggests that tourists do not evaluate authenticity from an intellectual awareness but through emotional experiences since the postmodern tourist is an affective-driven, experience-seeking hedonist (Kolar \& Žabkar 2010). In accordance with this thought, Kolar and Žabkar (2010) presented their own definition of authenticity as tourists' enjoyment and perceptions of how genuine their experiences of a cultural attraction are. In this understanding, authenticity in tourism is perceived by tourists as the sincerity of the tour guide's interpretation and as a sense of the mutual co-creation and involvement in the tourism experience, so that it enhances everybody's experience.

As a broad concept, authenticity in tourism can be viewed from various standpoints. Cohen (2007) describes authenticity as origins, as genuineness, as pristinity, as sincerity, as creativity and as flow of life. Emotional perception of sincerity is highly connected with positive spirit and state of mind, which can be evoked by using humour. Additionally, over time an objectively inauthentic experience can become constructed authenticity, where it acquires its own history, status and even nostalgic value. In this light, the concept of "quasification" introduced by Beardsworth and Bryman $(1999 ; 2001)$ makes sense, not as a negation of authenticity but as one of the more postmodern understandings of it, whereby the tourists are not intended to believe that the "fakes" are true, but rather to be "in on the joke", and entertained by the skills of the artifice. Humour, it seems, has the potential to be a mediator between the "objective authenticity" and the staged nature of the tourism product.

Barnett and Deutsch (2016) argue that authenticity is a key component in humour and quote Collins's (2004 in Barnett \& Deutsch 2016) idea that anyone can pretend to be serious, but you cannot pretend to be funny. Since authenticity in its traditional understanding is perceived as a serious concept (as it describes something as it really is), using humour seems rather unusual. Still, humour itself is genuine and sincere, since a true laugh cannot be faked. Humour as an authentic technique of communicating with others can thus be helpful in portraying the distinctiveness of attractions and even destinations. The authenticity of a destination can be 
presented through original (or exaggerated) accents, word use, jokes about other nationalities and a fast/slow speaking pace (Pabel \& Pearce 2018). Hence, it can be perceived as a playful manner of presenting a destination's cultural heritage. Weia, Qianb and Suna (2018) highlighted that irony and sarcasm are often recognised as techniques to preserve the authenticity of the host community. Using the term "joke-work", the authors describe how locals tell jokes at the expense of tourists, thus exposing the tourists' ignorance, while retaining their own superior knowledge of the authentic life of their own community. Cultural performances mixed with jokes, which make sense only to those having access to the backstage, become a safe method to temporarily reverse power dynamics (Weia, Qianb \& Suna 2018). Similarly, Goulding (2000) proposes parody and pastiche as postmodern methods of experiencing heritage. While mocking the original, the experience becomes humorous. Humour in the form of parody thus offers an effective post-modern communication strategy (Francesconi 2017).

Historical facts can be presented by using an anecdote or a joke. Attardo (2014) writes that even though anecdotes should be based on some real events, in postmodern times, authenticity or factuality cannot be used as means to differentiate anecdotes from obviously fictional jokes. What is important is how the anecdotes and jokes are presented as a means of providing a positive tourism experience. However, McDonald (2012) argues that humour is not always perceived as a positive factor. Humour is in fact associated with lies and when we joke, we take liberties with the truth, use duplicity and dissimulation. Thus, the authenticity in our communication is endangered. Therefore, the usage of humour in guided tours should be presented very carefully. Even though tour guides mostly follow a written script and perform learned jokes, they try to deliver them in a spontaneous way, thus demonstrating their sincerity and authenticity of communication (Uzelac, Nasar \& Lacbawan Jr. 2015; Pearce \& Pabel 2015).

\subsection{Research aim and hypotheses}

The current research was first based on a selection of a case study of a tourism product - one which attracts visitors based on the promise of edutainment: learning about history in a humorous manner.

The primary aim of the case study was to analyse the visitors' impressions of the humorous nature of the product. For that we focused on comparing Pearce's model of humour and Pine and Gilmore's 4Es model of experience design. There appear to be certain overlaps between Pearce's functions of humour and Pine and Gilmore's four dimensions of experience design, since both models emphasize cognitive aspects (concentration vs. education), social aspects (connection to presenters vs. entertainment) and personal aspects (comfort vs. escape). This study is thus an attempt to research the connection between the three functions of humour in tourism and the four dimensions of experience design. By connecting the two models we provide a number of hypotheses:

H1: Our first hypothesis is that the three functions of humour (comfort, concentration, and connection) in tourism products stimulate a more enjoyable experience and are thus positively correlated with all four dimensions of experience design (entertainment, education, escape and aesthetics), especially the entertainment dimension.

$\mathrm{H} 2$ : Our second hypothesis is that the extent to which tourists were involved in prior amusing and enjoyable activities, before participating in the selected staged product, is positively correlated with the level of participation in the tourism product. Tourists whose prior travel experiences have already resulted in a relaxed, positive and humorous atmosphere are more susceptible to participate in humorous experiences since they are more relaxed with their 
travel companions and are thus more at ease in terms of producing their own humour via participatory activities inherent to the product.

H3: Our third hypothesis is that the visitors' own engagement and their past experiences with the tourism product positively correlate with the four dimensions of experiences and with the three functions of humour in a tourism product. In this way, tourists are more susceptible to humour if they understand the assumptions on which the presented experience is based and are already in a favourable state of mind towards the experience.

The secondary goal of the research proved to be more challenging but potentially also more rewarding since it relates to a long-lasting debate on authenticity in tourism studies. The second goal of our research was to analyse the product from the point of view of theoretical debates on authenticity and humour in order to provide some first insights on how different types of authenticity connect with experience design of a humorous tourism product.

\section{Methods}

\subsection{Case study selection}

This study explores the use of humour in a tourism product called "Smart Head Primary School", which was launched on the market in 2010 and represents an example of using humour as a means for interactive interpretation of Bela Krajina heritage (a region of Slovenia). The product "Smart Head Primary School" is designed as a one-hour re-enactment of teaching as it happened in the 1950s. This case study was selected because humour in the context of authenticity and heritage interpretation is its main marketed value proposition. Humour is used as a fundamental mode of interpreting the cultural heritage of the region and the product itself would not be operating without the usage of humour. Other studies presented tourism products which are per se serious or of the adventure kind such as white-water rafting or skydiving (Pabel \& Pearce 2016; Pabel 2017). These types of tourism products generally add humour as an efficient way to relax visitors in high adrenalin environments or to lighten up the mood in the course of a guided tour where different unknown people come together. In this selected case, however, humour is the main value proposition of the product.

\subsection{Research design}

In order to analyse the intertwining of humour with heritage interpretation, the authors combine two research methods (a) a survey which was distributed to the visitors of the product; (b) an in-depth analysis of a transcribed video-recording of a sample performance, including the reflections by one of the "teachers" (one of the paper's authors). The first method was used to validate Pearce's (2009) functions of humour in relation to the four dimensions of experiences (Pine and Gilmore 1998; 1999). The second method provides an in-depth overview of the product's use of humour in relating to authenticity and the four dimensions of experiences (Pine \& Gilmore 1998; 1999). By this method, we analysed various meanings of the experience, documenting the process completely according to the data analysis spiral (Creswell 2007). This rigorous study includes interpretations from all three authors, including valuable insight comments from "the teacher" author. 


\section{Results}

\subsection{Visitor survey}

A questionnaire was distributed to the visitors to analyse their perceptions of the product and its use of humour. The questionnaire consisted of five groups of questions: (a) functions of humour, (b) experience design dimensions, (c) level of participation in the product, (d) pre-visit experiences, and (e) demographic questions.

We used Pabel and Pearce's (2016) operationalisation of Pearce's (2009) model of the functions of humour: comfort, connection, and concentration. We used Oh, Fiore \& Jeoung (2007) operationalisation of Pine and Gilmore's (1998) experience design dimensions: education, aesthetics, escapism and entertainment. To ensure consistency in measuring two constructs, both were rated on 5-point Likert scales. Overall the wording of the indicators stayed the same as in the original scales, however we translated the indicators and when necessary, made minor modifications to fit the context of the tourism product. All other indicators were developed by us, either using common standard items (gender, age and satisfaction) or developing our own measuring scales to fit the context of the product (pre-visit experience and own schooling experience).

The questionnaire was distributed to visitors of the tourism product "Smart Head Primary School" after they had experienced the product. The survey was conducted in October and November 2018. A total of 92 useable questionnaires were collected.

\subsubsection{Profile of the respondents}

Respondents were primarily women $(62.5 \%)$. All of them were adults, some of whom have themselves experienced the strict school environment as presented by the product. The oldest participant was born in 1937, and the youngest was born in 1996. The age range thus varies from 22 to 81, while the average age of the respondents was 53 years old. The sample consisted of only domestic respondents, however they originate from different parts of Slovenia, mostly from central Slovenia. When asked how their visit was organized, the majority answered that they visited the site as part of an organized group such as a workers' union or seniors' association trip (88\%). Most of the visits were made as a day trip around the Bela Krajina region, while others stated they celebrated a special day (part of birthday celebration, anniversary or similar).

\subsubsection{Perceiving the product: functions of humour, dimensions of experience design and general satisfaction}

On all of the items that were used to measure the visitor's perception of the product, the mean was 4.4 or higher on a 5-point Likert scale (see Table 1). The highest rating was received for the general level of satisfaction, reaching 4.9 on both items, indicating that nearly all visitors to "Smart Head Primary School" enjoyed their experience. This is supported by some of the visitors adding thank you messages or writing their own words of praise for the product next to the satisfaction scales. The lowest score, but still rather high with a mean of 4.4 was an education-based item in the experience design dimension ("I learned a lot"). None of the other measured variables stands out in terms of having lower scores.

Such results can primarily be explained by the fact that the results are a reflection of the selected product: we chose the "Smart Head Primary School" as a case study due to its high popularity and its successful inclusion of humour. The results in Table 1 indicate that the experience shows high scores for the functions of humour, the dimensions of experience design 
and overall satisfaction. To some extent, although it remains only a speculation at this point, we may consider the results as being a consequence of the positivity bias. This might have happened because within that one hour of social interaction within the product, enough rapport was built between the visitors and the "teacher" that the visitors do not wish to be too critical in their evaluations. Another reason might be that showing humour appreciation is a way to build one's own positive self-perception as a "fun" person.

Table 1. Mean ratings, standard deviations and minimum and maximum scores for functions of humour, dimensions of experience design and overall satisfaction $(\mathrm{n}=92)$

\begin{tabular}{|c|c|c|c|c|}
\hline & $\mathrm{M}$ & SD & Min & Max \\
\hline \multicolumn{5}{|c|}{ Functions of humour (Pabel \& Pearce 2016) (variable index: mean of all items per function) } \\
\hline Made me feel at ease with the tour (comfort) & 4.8 & 0.5 & 2 & 5 \\
\hline Creation of cheerful atmosphere (comfort) & 4.7 & 0.7 & 1 & 5 \\
\hline Keeps me more alert (concentration) & 4.5 & 0.8 & 1 & 5 \\
\hline Helps me understand explanations (concentration) & 4.8 & 0.6 & 2 & 5 \\
\hline Connection with the tour guide (connection) & 4.6 & 0.7 & 1 & 5 \\
\hline Connection with other tourists (connection) & 4.8 & 0.5 & 2 & 5 \\
\hline \multicolumn{5}{|c|}{ Dimensions of experience design (Oh, Fiore \& Jeoung 2007) (variable index: mean of all items per dimension) } \\
\hline The experience has made me more knowledgeable (education) & 4.6 & 0.6 & 3 & 5 \\
\hline I learned a lot (education) & 4.4 & 0.7 & 3 & 5 \\
\hline It was a real learning experience (education) & 4.8 & 0.5 & 3 & 5 \\
\hline The setting was very attractive (aesthetics) & 4.8 & 0.5 & 3 & 5 \\
\hline The setting really showed attention to design detail (aesthetics) & 4.6 & 0.6 & 3 & 5 \\
\hline I felt a real sense of harmony with the exhibited objects and with the "classroom" (aesthetics) & 4.7 & 0.5 & 3 & 5 \\
\hline I felt like I was living in a different time or place (escapism) & 4.5 & 0.7 & 3 & 5 \\
\hline I could imagine how it was like to be a pupil in those times (escapism) & 4.5 & 0.8 & 2 & 5 \\
\hline I escaped from my everyday reality (escapism) & 4.7 & 0.6 & 3 & 5 \\
\hline Activities of others were amusing to watch (entertainment) & 4.9 & 0.4 & 4 & 5 \\
\hline Watching "the teacher" perform was captivating (entertainment) & 4.8 & 0.5 & 4 & 5 \\
\hline The "teacher's" "strict" performance was funny (entertainment) & 4.8 & 0.5 & 3 & 5 \\
\hline I found the "teacher's" jokes funny (entertainment) & 4.8 & 0.5 & 3 & 5 \\
\hline I was bored at times (reverse coded) (entertainment) & 4.5 & 1.2 & 1 & 5 \\
\hline \multicolumn{5}{|l|}{ Satisfaction (variable index: mean of all items) } \\
\hline I was satisfied with this visit & 4.9 & 0.3 & 4 & 5 \\
\hline I would recommend my family and friends to visit this product & 4.9 & 0.2 & 4 & 5 \\
\hline
\end{tabular}

The very similar data dispersion amongst the three types of variables is also reflected in the very high levels of correlation amongst the variable indexes (measured as the mean value of the items combining each variable). Table 2 shows the Pearson correlations for each of the perception variables indexes in combination with each of the other perception variable indexes. In most cases, the Pearson correlation is between 0.3 and 0.6, indicating a high level of correlation. Only three of the combinations do not show a statistical correlation, all three in the case of concentration: concentration and the aesthetics dimension, concentration and the entertainment dimension, and concentration and satisfaction. More research is needed to discern why exactly the concentration function of humour stands out and whether this is a characteristic in general or if it is specific to this case study.

Although the results are based on only one case study and a small sample of respondents, we are tentatively concluding that the measured variables provide a good indication of how the product was perceived by the respondents. We cannot draw any definite conclusions about any cause and effect relationships between the perceived functions of humour, the perceptions of the experience design dimensions and the satisfaction ratings. Rather, in line with the general human tendency of cognitive dissonance (Festinger 1962), we argue that these concepts are all part of the broader impressions in response to a particular tourism product, albeit on different measures of perception. 
Table 2. Pearson correlations of variable indexes (mean on all items) of maximum scores for functions of humour, dimensions of experience design and overall satisfaction $(n=92)$

\begin{tabular}{|c|c|c|c|c|c|c|c|c|}
\hline & & Escape & Aesthetics & Entertainment & Comfort & Connection & Concentration & Satisfaction \\
\hline \multirow[t]{3}{*}{ Education } & Pearson &, $530^{* *}$ & ,598 &, $358^{* * *}$ &, $304^{*}$ &, $318^{* *}$ &, $454^{* *}$ &, $467 * *$ \\
\hline & \begin{tabular}{|l|} 
Sig. \\
\end{tabular} &, 000 & 000 & 003 &, 012 &, 009 & 000 & 000 \\
\hline & \begin{tabular}{|l|}
$\mathrm{N}$ \\
\end{tabular} & 67 & 68 & 68 & 67 & 67 & 67 & 68 \\
\hline \multirow[t]{3}{*}{ Escape } & Pearson & &, $665^{* *}$ &, $345^{* *}$ &, $427^{* *}$ &, $603^{* *}$ & ,271* &, $397 * *$ \\
\hline & Sig. & & ,000 & ,004 & ,000 & ,000 &, 025 & ,001 \\
\hline & $\mathrm{N}$ & & 68 & 68 & 68 & 68 & 68 & 68 \\
\hline \multirow[t]{3}{*}{ Aesthetics } & Pearson & & &, $374^{* *}$ &, $255^{*}$ &, $326^{* *}$ & ,167 &, $577 * *$ \\
\hline & \begin{tabular}{|l} 
Sig. \\
\end{tabular} & & & ,002 &, 036 & 007 &, 173 & ,000 \\
\hline & \begin{tabular}{|l|}
$\mathrm{N}$ \\
\end{tabular} & & & 69 & 68 & 68 & 68 & 69 \\
\hline \multirow{3}{*}{ Entertainment } & Pearson & & & & $296^{*}$ & ,107 & ,032 & $311 * *$ \\
\hline & \begin{tabular}{|l} 
Sig. \\
\end{tabular} & & & & ,013 & ,383 & ,794 & ,009 \\
\hline & $\mathrm{N}$ & & & & 69 & 69 & 69 & 70 \\
\hline \multirow[t]{3}{*}{ Comfort } & Pearson & & & & &, $620^{* *}$ &, $434^{* *}$ & ,260* \\
\hline & \begin{tabular}{|l|} 
Sig. \\
\end{tabular} & & & & & ,000 & ,000 &, 030 \\
\hline & $\mathrm{N}$ & & & & & 91 & 90 & 70 \\
\hline \multirow{3}{*}{ Connection } & Pearson & & & & & &, $523^{* * *}$ & ,296* \\
\hline & \begin{tabular}{|l} 
Sig. \\
\end{tabular} & & & & & &, 000 &, 013 \\
\hline & \begin{tabular}{|l|}
$\mathrm{N}$ \\
\end{tabular} & & & & & & 90 & 70 \\
\hline \multirow[t]{3}{*}{ Concentration } & Pearson & & & & & & & ,220 \\
\hline & \begin{tabular}{|l|} 
Sig. \\
\end{tabular} & & & & & & & ,067 \\
\hline & $\mathrm{N}$ & & & & & & & 70 \\
\hline
\end{tabular}

**. Correlation is significant at the 0.01 level (2-tailed).

*. Correlation is significant at the 0.05 level (2-tailed).

\subsubsection{Respondents' participation in the product, pre-visit experiences and own schooling experience}

Respondents were asked about the number of activities they had engaged with while attending the product. Table 3 indicates that the level of participation was high. Almost all respondents $(98 \%)$ reported that they participated in the singing while being in the role of the "pupils" $(92 \%)$. Most gave answers to the "teacher's" questions (92\%) and joked out loud (90\%). More than half reported that they went in front of the whole class to write on the blackboard (57\%) and almost half $(42 \%)$ performed the role of the "naughty" pupil by contradicting the "teacher".

Table 3. Level of participation in product activities

\begin{tabular}{|c|c|c|}
\hline & \multicolumn{2}{|c|}{ YES } \\
\hline \multicolumn{3}{|c|}{ Participation in product activities (variable index: SUM of all items) } \\
\hline Did you do any of the following activities in the "lecture room" today? & $\mathrm{n}$ & $\%$ \\
\hline Sang & 90 & 98 \\
\hline Answered the "teacher's" questions & 83 & 92 \\
\hline Joked out loud & 82 & 90 \\
\hline Went in front of the class to write or draw on the blackboard & 52 & 57 \\
\hline Contradicted the teacher & 39 & 42 \\
\hline
\end{tabular}

Table 4 shows the pre-visit experience respondents had before participating in the product. These items set out to measure the extent to which they have managed to build a relaxed atmosphere amongst their fellow travellers before the trip. The scores were again skewed towards the higher end of the Likert scales. All three measures had scores of 4.8 or above. 
The only items in this research that do not show extremely high mean values asked respondents about their own schooling experiences and to reflect on how similar the staged schooling experience was to their own schooling experience. Here the distribution of the index is much more similar to a normal distribution, with specific items ranging from mean scores of 2.2 to 4.8. However, when performing a regression analysis between the independent variable of 'pre-visit experience' and the dependent variable of 'participation in product activities', we found that there was no statistically significant correlation (St. Coefficient Beta -0.182 ; $\mathrm{t}-1,572$; Sig. 0.120).

Table 4. Mean ratings, standard deviations and minimum and maximum scores for pre-visit experience and own schooling experiences $(n=92)$

\begin{tabular}{|c|c|c|c|c|}
\hline & $\mathrm{M}$ & SD & Min & Max \\
\hline \multicolumn{5}{|l|}{ Pre-visit experience (variable index: mean of all items) } \\
\hline \multicolumn{5}{|l|}{ Before we visited the product today we already: } \\
\hline Had a relaxed atmosphere on the trip. & 4.9 & 0.3 & 3 & 5 \\
\hline Joked out loud amongst ourselves. & 4.8 & 0.5 & 3 & 5 \\
\hline Got to know each other very well. & 4.9 & 0.3 & 3 & 5 \\
\hline \multicolumn{5}{|l|}{ Own schooling experience (variable index: mean of all items) } \\
\hline \multicolumn{5}{|l|}{ When I visited school myself: } \\
\hline The teachers were very serious. & 3.9 & 1.2 & 1 & 5 \\
\hline We were physically punished for not knowing correct answers (e.g., with kneeling on corn). & 2.2 & 1.6 & 1 & 5 \\
\hline We were allowed to talk only if we raised our hand beforehand. & 4.0 & 1.3 & 1 & 5 \\
\hline The teachers were very strict. & 3.9 & 1.1 & 1 & 5 \\
\hline The classrooms were similar to the one we were in today. & 3.1 & 1.6 & 1 & 5 \\
\hline We had to write on the blackboard with chalk. & 4.8 & 0.7 & 1 & 5 \\
\hline
\end{tabular}

Finally, a regression analysis was performed with the 8 product perception variables as dependent variables. The independent variables in the model were participation in the products' activities, own schooling experience, pre-visit experience, plus age and gender (see Table 5). Only two correlations showed statistically significant results. The first is gender and the education dimension of experience design: in this case female participants showed higher levels of perceiving the product as educational that male participants. The second statistically significant correlation exists between participants' own schooling experience and the connection function of humour. Participants who perceived the product as more similar to their own schooling experience, thus in a way as more objectively authentic, showed higher levels of connections to other "pupils" and the "teacher".

Table 5. Regression analysis coefficients

\begin{tabular}{|l|l|c|c|c|c|c|c|c|c|}
\hline \multicolumn{2}{|l|}{} & Education & Escape & Aesthetics & Entertainment & Comfort & Connection & Concentration & Satisfaction \\
\hline \multirow{2}{*}{$\begin{array}{l}\text { Participation } \\
\text { in product } \\
\text { activities }\end{array}$} & $\begin{array}{l}\text { St. } \\
\text { Coefficient } \\
\text { Beta }\end{array}$ & 0.07 & 0.04 & 0.08 & 0.08 & 0.04 & 0.04 & 0.30 & -0.04 \\
\cline { 2 - 11 } & $\mathrm{t}$ & -0.57 & 0.32 & 0.56 & 0.55 & 0.32 & 0.35 & 0.24 & -0.24 \\
\cline { 2 - 11 } & Sig. & 0.57 & 0.75 & 0.58 & 0.59 & 0.75 & 0.73 & 0.81 & 0.81 \\
\hline $\begin{array}{l}\text { Own } \\
\text { schooling } \\
\text { experience }\end{array}$ & $\begin{array}{l}\text { St. } \\
\text { Coefficient } \\
\text { Beta }\end{array}$ & 0.21 & 1,56 & 0.16 & 0.00 & 0.16 & $\mathbf{0 . 3 8}$ & 0.20 & 0.09 \\
\cline { 2 - 11 } & $\mathrm{t}$ & 1,61 & 1,25 & 1,16 & 0.01 & 1,25 & 3,20 & 1,65 & 0.64 \\
\cline { 2 - 11 } & Sig. & 0.11 & 0.22 & 0.25 & 0.99 & 0.22 & 0.00 & 0.10 & 0.53 \\
\hline \multirow{2}{*}{$\begin{array}{l}\text { Pre-visit } \\
\text { experience }\end{array}$} & $\begin{array}{l}\text { St. } \\
\text { Coefficient } \\
\text { Beta }\end{array}$ & 0.23 & 0.88 & 0.12 & 0.08 & 0.09 & 0.07 & 0.16 & 0.03 \\
\cline { 2 - 11 } & $\mathrm{t}$ & 1,78 & 0.70 & 0.90 & 0.60 & 0.70 & 0.63 & 1,25 & 0.24 \\
\cline { 2 - 10 } & Sig. & 0.09 & 0.49 & 0.37 & 0.56 & 0.49 & 0.53 & 0.22 & 0.81 \\
\hline
\end{tabular}




\begin{tabular}{|c|c|c|c|c|c|c|c|c|c|}
\hline \multirow[t]{3}{*}{ Age } & \begin{tabular}{|l|} 
St. \\
Coefficient \\
Beta \\
\end{tabular} & -0.10 & 0.49 & 0.15 & -0.01 & 0.05 & -0.02 & 0.12 & -0.02 \\
\hline & $\mathrm{t}$ & -0.08 & 0.39 & 1,06 & -0.10 & 0.39 & -0.15 & 0.94 & -0.12 \\
\hline & \begin{tabular}{|l|} 
Sig. \\
\end{tabular} & 0.94 & 0.70 & 0.29 & 0.92 & 0.70 & 0.89 & 0.35 & 0.91 \\
\hline \multirow[t]{3}{*}{ Gender } & \begin{tabular}{|l|} 
St. \\
Coefficient \\
Beta \\
\end{tabular} & $0.36^{*}$ & 0.85 & 0.24 & ,23 & 0.09 & -0.07 & 0.04 & 0.08 \\
\hline & $\mathrm{t}$ & 2,83 & 0.67 & 1,77 & 1,62 & 0.67 & -0.58 & 0.33 & 0.53 \\
\hline & \begin{tabular}{|l|} 
Sig. \\
\end{tabular} & 0.01 & 0.50 & 0.08 & 0.11 & 0.50 & 0.57 & 0.74 & 0.60 \\
\hline
\end{tabular}

\subsection{In-depth analysis of the case study's humour}

The in-depth analysis of a transcribed video-recording of a sample performance of "Smart Head Primary School" shows that the product puts emphasis on all four dimensions of experience design: education, aesthetics, escape and entertainment.

The educational dimension of the experience makes up the bulk of the content of the experience. Visitors are welcomed by the "headmaster" and a very strict "teacher", who perform in the following languages: Slovenian, Croatian, English, German or Italian. The experience is based on a teaching hour to interpret to the "pupils" (visitors) prime elements of the region's heritage and local characteristics. This includes geographical features, culinary specialities, regional ethnic costumes, folk songs and instruments, artisan products and the character of the inhabitants of the region. The school visit ends with the graduation ceremony where the teacher hands out the report cards and, if visitors have pre-ordered it, they can also get a traditionally made school lunch consisting of local ingredients from the destination. The main topics of heritage interpretation are selected from known and published stories, legends, customs and fables from the most respected local authors, thus aiming for a representation of objective authenticity of the local heritage. The interpretation, however, also steps into the realm of constructive or symbolic authenticity since the character of the inhabitants of the region and some local characteristics are presented in a rather beautified manner from the local inhabitants' perspective. It is in this tension between the objective authenticity and the constructive authenticity that the use of humour seems to serve its purpose: the "teacher" is aware of the constructive nature of the interpretation and uses jokes and irony to present such constructive authenticity, as for example in the case of the host's perception of their own hospitality:

"What is the difference between a person from Bela Krajina and a person from Gorenjska region? Humongous! The Gorenjska man invites a passenger by with the words 'Come, you will see my new house!' Bela Krajina man says 'Come, you will taste my new wine!' And if you happen to find yourself on a wine route in Bela Krajina, you are bound to see a Bela Krajina man come from somewhere with a litre of wine in his hand to offer you a glass of wine. Do not turn him down! You would insult him. Try the wine and praise it! The Bela Krajina man is a hospitable and sociable human being".

Secondly, the product puts emphasis on the objective authenticity of the aesthetics dimension of the experience, creatively exploiting heritage resources without the need for large investments. The experience is located in an old school building where the actual teaching used to take place. It is situated within a classroom that is decorated with original classroom furniture and artefacts such as pupil's benches, green chalkboard, teacher's stick, an old wooden calculator, pictures of Slovenia's most important literary figures, then communist party leader Tito, and examples of local musical instruments. The classroom is thus decorated with the objectively authentic artefacts of the time it wishes to represent. However, it also includes 
artefacts that one would not necessarily expect in a classroom of the time but serve the purpose of interpreting the local heritage and are objectively authentic representations of the heritage, for example the regional ethnic costumes and traditionally coloured Easter eggs. This objective authenticity is not humorous per se, but it becomes an object of amusement when visitors compare the visited site to present-day classrooms and find it funny that pupils ever wrote on wooden tablets or used wooden calculators (see Figure 1 below).

Thirdly, by its interactive, "staged" re-enactment of history, the product builds the escape dimension of an experience. The reflections by one of the "teachers" on the scripted versus spontaneous humour of the product shows that the product is highly scripted, with the script including a large amount of humour in the product. At the same time, however, the interpreters are recommended to be able to improvise and use spontaneous humour, by being able to judge the situation and characteristics of the group that is currently visiting the school. This is done primarily through increasing the interactive, participatory nature of the product. The visitors are highly involved in the delivery of the product itself, since they are invited to sing, draw with chalk on an old green chalkboard, answer questions or even kneel on the corn seeds, if they "behaved naughtily". Hence, much of the humour of the product relies on the co-creation of the experience with the "pupils" providing wrong or amusing answers. It is the dimension of the "escape" into history, where the product faces the highest tension between objective and existential authenticity.

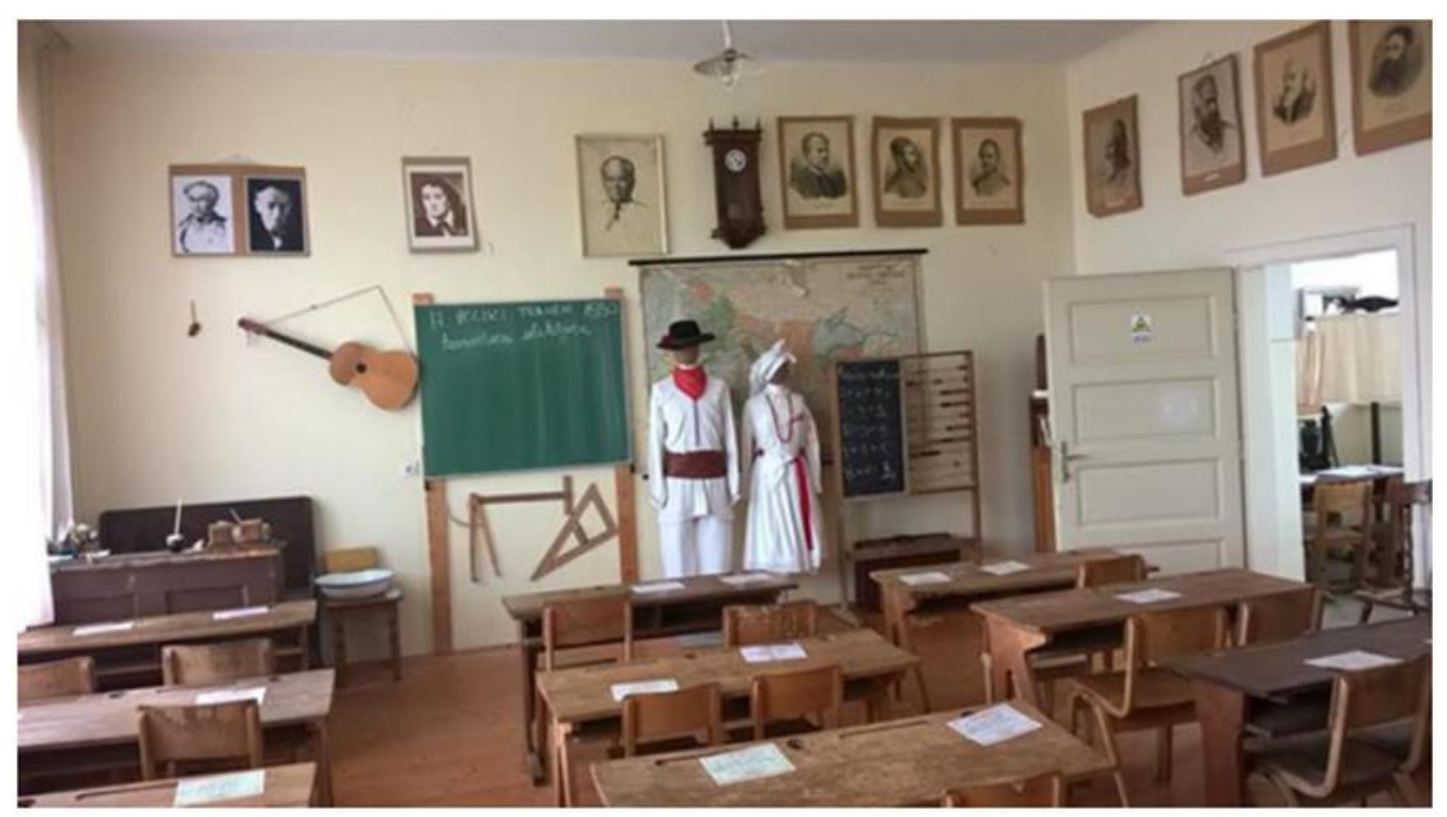

Figure 1: The classroom environment of the product "Smart Head". Source: Tatjana Zupančič

On the one hand, the objective authenticity creates the basis of the strict teachers' role, whereby the teacher uses a strong authoritative voice, walks around the classroom with a stick in her hands and orders the "pupils" what to do and when to answer questions. On the other hand, the objective authenticity of the teacher is "quasified" in Beardsworth and Bryman's (2001) use of the term, where the intention is that the visitors are "in on the joke", and hence diverted, entertained and impressed by the "staged" nature of the experience and thus willing to play the roles of naughty pupils and not fear but be amused by the "teacher's" performance. All these activities can enhance the existential authenticity whereby the tourists can enjoy their Open-access journal $\mid$ www.europeanjournalofhumour.org 
mischievous self and play the role of naughty pupils in a safe environment without any serious consequences. They can be playful, they can sing, draw, speak up and therefore express themselves and at the same time attract positive attention from the "teacher" and other visitors.

Finally, and overarching, is the dimension of entertainment in the design of this experience. The entertainment experience is commonly described as situations when tourists passively observe activities and/or performances of others and reflect on them as being "fun" (Oh, Fiore \& Jeoung 2007). In the present case, the tourism product puts great emphasis on visitor participation and co-creation of the experience, but still there are visitors who rather just observe the activities around them and do not answer the teacher's questions. The teacher is thus advised to address only visitors who show involvement with the experience and are responsive. Others are left to enjoy the fun conversations of more active visitors, their awkward drawings, "wrong" answers and the teacher's humorous "correct" answers. And while the teacher addresses different visitors, everybody gets to be entertained by others' participation, if not their own. Entertainment in the product is hence a passive manner of learning about historical facts while using objective authenticity (tourists watch one of the visitors play an old local instrument) or constructive authenticity (learning about the local river while the visitors observe one "pupil" draw various fish that symbolically represent different countries the river divides).

\section{Discussion and conclusion}

This study set out to investigate visitors' perceptions of a humorous tourism product named "Smart Head Primary School" in the Bela Krajina region of Slovenia on a range of variables including experience design, humour functions and satisfaction ratings. While we cannot draw any definite conclusions about any cause and effect relationships between the measured variables, we can see some interconnection amongst the concepts which were tested in our survey research. Moreover, the presented concepts are also intertwined with the concept of authenticity as outlined in the in-depth analysis of the transcribed video-recording of a sample performance and through the reflections by one of the "teachers".

The presented study is one of the first to develop a model based on humour and experience design. Knowledge of this kind is vital for the design of visitor experience heritage interpretation. The study showed that humorous stories combined with historical facts lead to a unique and enjoyable tourism experience.

The survey results show possible overlaps of Pearce's (2009) model of the three functions of humour in tourism and Pine and Gilmore's (1999) four dimensions of experience design. The correlation between the variables of concentration and education refers to cognitive aspects of perceiving tourism products, while the correlation between the variables of comfort and escape refers to personal aspects of perceiving tourism products. However, no significant correlation could be reported between the variables of connection to the presenter and entertainment. The entertainment variable correlates only with the comfort function of humour, indicating that the type of entertainment used during the experience made respondents feel comfortable with the setting. The connection function of humour showed the strongest correlation with the escape dimension. This highlights that respondents felt connected to the experience in that the humorous presentations by the "teacher" allowed them to escape to a different place and time.

Regarding the second and the third hypothesis, results proved to be even more challenging. Although we made the assumption that the extent to which the tourists were involved in enjoyable activities before participating in the selected tourism product would positively correlate with the level of participation in the tourism product, this could not be verified since no statistically significant correlations were noted. The same happened with our third 
hypothesis, which should be rejected since no significant correlation between variables could be reported.

Only the variable of "own schooling experience" indicated a statistically significant correlation with the connection function of humour. And this is the area that is still most intriguing and in need of further research. More research is needed into the interrelations between the analysed variables - especially on how past experiences with a seemingly scary or negative event (like strict teachers) affect the functions of humour. Why for example was there a statistically significant correlation between the connection function of humour and the respondents' own schooling experience (hence perceive objective authenticity of the product), but not other functions of humour?

The long-disputed concept of authenticity was examined through an in-depth analysis of a sample performance of the tourism product. In this case, we provide some first tentative answers that need to be further researched: we hypothesize for the future research that humour appears to ease the tension between objective authenticity and constructive authenticity. Interpretation of constructive authenticity in the product is intertwined with jokes and irony and therefore visitors can perceive what is actually real in the narration - they can distinguish objective reality from interpreted one. Similarly, humour also appears to support the reduction of tension between the objective authenticity and existential authenticity. Objectively, the circumstances are not pleasant - there is a strict teacher, who has the means to punish the wrong answers and disobedient pupils / visitors. Hence, visitors should be frightened and not prepared to express their own mind or talents. But with the use of humour, visitors feel safe and relaxed and are therefore prepared to sing, draw, play and give humorous responses to the teacher's questions they can be themselves in the sense of existential authenticity. However, this presented interpretation is a product of the three authors of this paper and therefore limited in its meaning. Further research involving visitors' responses is needed in order to provide more conclusions on how exactly humour mediates between different types of authenticity. The second objective of this research thus still remains a challenge: the analysis of the interconnection between authenticity and humour is still in its tentative stage.

Additional research is also needed on tourism cases that do not feature such a high and effective use of humour, which may result in a more even distribution of visitor ratings on the measuring scales. This would also enable us to compare any differences in perceptions of the humour functions, the experience design dimensions and satisfaction levels across different tourism settings and different cultures. It is important to note that this research is limited to the specific cultural background of Slovenia and that the results are culturally limited.

Despite the limitations of this research, we nevertheless believe that humour can be perceived as one of the most effective and most pleasant methods of experiencing the authenticity of a tourism site and embracing the authenticity of the tourists themselves. Humour just might be the connecting line between objective and constructive authenticity, contributing to a more memorable cognitive experience, creating a pleasant atmosphere and above all, it seems to be a tool that aids in coping with negative memories and transforming them into new pleasant experiences.

\section{References}

Attardo, S. (2014). Encyclopedia of Humor Studies. Los Angeles: Sage.

Barnett, M. D. \& Deutsch, J. T. (2016). 'Humanism, authenticity, and humor: Being, being real, and being funny'. Personality and Individual Differences 91, pp. 107-112.

Beardsworth, A. \& Bryman, A. (1999). 'Late modernity and the dynamics of quasification: the case of the themed restaurant'. The Sociological Review 47 (2), pp. 228-257. 
Beardsworth, A. \& Bryman, A. (2001). 'The wild animal in late modernity: The case of the Disneyization of zoos'. Tourist Studies 1 (1), pp. 83-104.

Bryman, A. (1999). 'The Disneyization of society'. The Sociological Review 47 (1), pp. 25-47.

Chhabra, D., Healy, R. \& Sills, E. (2003). 'Staged authenticity and heritage tourism'. Annals of Tourism Research 30 (3), pp. 702-719.

Cohen, E. (1988). 'Authenticity and commoditization in Tourism'. Annals of Tourism Research 15 (3), pp. 371-386.

Cohen, E. (2007). 'Authenticity in Tourism Studies: Après la lutte'. Tourism Recreation Research 32 (2), pp. 75-81.

Creswell, J. W. (2007). Qualitative Inquiry and Research Design: Choosing among Five Approaches. Thousand Oaks, CA: Sage.

Evans-Pritchard, D. (1989). 'How "they" see "us": Native American images of tourists'. Annals of Tourism Research 16, pp. 89-105.

Francesconi, S. (2017). 'Dynamic intersemiosis as a humour-enacting trigger in a tourist video'. Visual Communication 16 (4), pp. 395-425.

Festinger, L. (1962). 'Cognitive dissonance'. Scientific American 207 (4), pp. 93-106.

Frew, E. (2006a). 'Humorous sites: An exploration of tourism at comedic TV and film locations'. Tourism Culture \& Communication 6 (3), pp. 205-208.

Frew, E. (2006b). 'The humour tourist: A conceptualisation'. Journal of Business Research 59, pp. 643-646.

Gaoa, J. \& Kerstetterb, D. L. (2018). 'From sad to happy to happier: Emotion regulation strategies used during a vacation'. Annals of Tourism Research 69, pp. 1-14.

Goffman, E. (1959). The Presentation of Self in Everyday Life. Garden City, NY: Doubleday.

Goulding, C. (2000). 'The commodification of the past, postmodern pastiche, and the search for authentic experiences at contemporary heritage attractions'. European Journal of Marketing 34 (7), pp. 835-853.

Heidegger, M. (1962). Being and Time. Oxford: Blackwell Publishing.

Hochschild, A. R. (1983). The Managed Heart: Commercialisation of Human Feeling. Berkeley: University of California Press.

Jurowski, C. (2009). 'An examination of the four realms of tourism experience theory'. Paper presented at the International CHRIE Conference-Refereed Track. Retrieved January 18, 2019 from:

https://scholarworks.umass.edu/cgi/viewcontent.cgi?article=1054\&context=refereed.

Kim, J.-H., Ritchie, J. B. \& McCormick, B. (2012). 'Development of a scale to measure memorable tourism experiences'. Journal of Travel Research 51 (1), pp. 12-25.

Knudsen, D. C, Rickly, J. M. \& Vidon, E. S. (2016). 'The fantasy of authenticity: Touring with Lacan'. Annals of Tourism Research 58, pp. 33-45.

Kolar, T. \& Zabkar, V. (2010). 'A consumer-based model of authenticity: An oxymoron or the foundation of cultural heritage marketing?' Tourism Management 31, pp. 652-664.

Lehtovuori, H. (2016). Utilization of Humour in a Tourism Service Encounter When Creating a Service Experience. Master's Thesis. University of Oulu, Oulu Business School.

MacCannell, D. (1973). 'Staged authenticity: Arrangements of social space in tourist settings'. American Journal of Sociology 79 (3), pp. 589-603.

McDonald, P. (2012). The Philosophy of Humour. Penrith, CA: Humanities-Ebooks.

Mehmetoglu, M. \& Engen, M. (2011). 'Pine and Gilmore's concept of experience economy and its dimensions: An empirical examination in tourism'. Journal of Quality Assurance in Hospitality \& Tourism 12 (4), pp. 237-255.

Moscardo, G. M. \& Pearce, P. L. (1986). 'Historic theme parks: An Australian experience in authenticity'. Annals of Tourism Research 13 (3), pp. 467-479. 
Moscardo, G. (1996). 'Mindful visitors: Heritage and tourism'. Annals of Tourism Research 23 (2), pp. 376-397.

Oh, H., Fiore, A. M. \& Jeoung, M. (2007). 'Measuring experience economy concepts: Tourism applications'. Journal of Travel Research 46 (2), pp. 119-32.

Pabel, A. (2017). 'The role of humour in contributing to tourism experiences', in Filep, S., Laing, J. \& Csikszentmihalyi, M. (eds.), Positive Tourism. New York: Routledge.

Pabel, A. \& Pearce, P. L. (2015). 'Highlighting the benefits of tourism humour: The views of tourists'. Tourism Management Perspectives 16, pp. 357-364.

Pabel, A. \& Pearce, P. L. (2016). 'Tourists' responses to humour'. Annals of Tourism Research 57, pp. 190-205.

Pabel, A. \& Pearce, P. L. (2018). 'Selecting humour in tourism settings: A guide for tourism operators'. Tourism Management Perspectives 25, pp. 64-70.

Pearce, P. L. (2005). Tourist Behaviour: Themes and Conceptual Schemes. Clevedon: Channel View Publications.

Pearce, P. L. (2008). 'Studying tourism entertainment through micro-cases'. Tourism Recreation Research 33 (2), pp. 151-163.

Pearce, P. L. (2009). 'Now that is funny. Humour in tourism settings'. Annals of Tourism Research 36 (4), pp. 627-644.

Pearce, P. L. \& Pabel, A. (2015). Tourism and Humour. Bristol: Channel View Publications.

Peterson, C. \& Seligman, M. E. P. (2004). Character Strengths and Virtues: A Handbook and Classification. Washington, DC: American Psychological Association.

Pine, B. J. \& Gilmore, J. H. (1998). 'Welcome to the experience economy'. Harvard business review 76, pp. 97-105.

Pine, B. J. \& Gilmore, J. H. (1999). The Experience Economy: Work is Theatre \& Every Business a Stage. Boston: Harvard Business Press.

Radder, L. \& Han, X. (2015). 'An examination of the museum experience based on Pine and Gilmore's experience economy realms'. Journal of Applied Business Research 31 (2), pp. $455-470$.

Sedmak, G. (2010). 'Avtentičnost in kakovost turističnega proizvoda Slovenske istre. (Authenticity and quality of Istria tourism product)'. Annales 20 (1), pp. 177-188.

Slivar, I., Periša, A. \& Horvat, A. (2018). 'Destination marketing organisations' use of humour and co-creation: an exploratory study from Croatia'. Interdisciplinary Description of Complex Systems 16 (2), pp. 238-248.

Sweet, J. (1989). 'Burlesquing “the other" in Pueblo performance'. Annals of Tourism Research 16, pp. 62-75.

Uzelac, K., Nasar, S. \& Lacbawan Jr., M. B. (2015). 'That was a joke, you should laugh! Tour guides and the performance of history in Budapest, Hungary'. Stud. ethnol. Croat. 27, pp. 307-326.

Vidon, E. S., Rickly, J. M. \& Knudsen, D. C. (2018). 'Wilderness state of mind: Expanding authenticity'. Annals of Tourism Research 73, pp. 62-70.

Walls, A. R., Okumus, F., Wang, Y. R. \& Kwun, D. J.-W. (2011). 'An epistemological view of consumer experiences’. International Journal of Hospitality Management 30 (1), pp. 1021.

Wang, N. (1999). 'Rethinking authenticity in tourism experience'. Annals of Tourism Research 26 (2), pp. 349-370.

Weia, L., Qianb, J. \& Suna, J. (2018). 'Self-orientalism, joke-work and host-tourist relation'. Annals of Tourism Research 68, pp. 89-99.

Zhang, H. Q. \& Chow, I. (2004). 'Application of importance-performance model in tour guides' performance: Evidence from mainland Chinese outbound visitors in Hong Kong'. Tourism Management 25 (1), pp. 81-91. 